\title{
Hubungan Aktivitas Fisik Terhadap Konstipasi pada Pasien Stroke di RS Islam Siti Rahmah Padang
}

\author{
Maria Valentina Sibarani ${ }^{1}$, Rahmi Ulfah², Esi Afriyanti ${ }^{3}$
}

\begin{abstract}
Abstrak
Konstipasi merupakan keluhan yang sangat sering pada pasien stroke, jika tidak diatasi akan menyebabkan komplikasi penyakit lainnya. Konstipasi pada pasien stroke bisa disebabkan oleh berbagai faktor, salah satunya diperberat oleh aktivitas fisik yang kurang. Tujuan: Menentukan korelasi aktifitas fisik terhadap konstipasi pada pasien stroke di RS Islam Siti Rahmah Padang. Metode: Subjek penelitian adalah pasien stroke sebanyak 54 orang. Desain penelitian ini adalah cross sectional dengan teknik pengambilan sampel secara simple random sampling. Pengukuran konstipasi menggunakan Constipation Scoring System (CSS) dan untuk menilai aktifitas fisik digunakan International Physical Activity Quosioner (IPAQ). Analisa statisitik dilakukan dengan uji korelasi Spearmen. Hasil: Responden dengan aktifitas rendah dan mengalami konstipasi berjumlah 34 orang $(87,18 \%)$. Hal ini menunjukan terdapat hubungan yang kuat dan bersifat positif antara aktivitas fisik dan konstipasi pada pasien stroke $(p=0,000, r=$ 0,608). Simpulan: Terdapat hubungan aktifitas fisik terhadap konstipasi pada pasien stroke di RS Islam Siti Rahmah padang
\end{abstract}

Kata Kunci : aktivitas Fisik, konstipasi, stroke

\begin{abstract}
Constipation is a very frequent complaint in stroke patients, if not treated will lead to complications of other diseases. Constipation in stroke patients can be caused by various factors, such as lack of activity. Objectives: To determined the relationship of physical activity on constipation in stroke patients at Siti Rahmah Padang Islamic Hospital. Methods: The samples were 54 stroke patients. The design of this study was cross sectional with a simple random sampling technique. The constipation questionnaire used by the Constipation Scoring System (CSS) and assess physical activity is used the International Physical Activity Quosioner (IPAQ). Static analysis is performed by the Spearmen correlation test. Results: Respondents with low activity and constipation were 34 people (87.18\%). The results showed a strong and positive relationship between physical activity and constipation in stroke patients ( $p=$ $0.000, r=0.608)$. Conclusion: There is a relationship between physical activity and constipation in stroke patients at Siti Rahmah Islam Hospital Padang
\end{abstract}

Keywords:physical activity, constipation, stroke

Affiliasi penulis: 1. Prodi Magister Fakultas Keperawatan Universitas Andalas. 2. RSUD Rasidin Padang. 3. Fakultas Keperawatan Universitas Andalas Padang.

Korespondensi: Maria Valentina Sibarani, Email: Mariavalentinasibarani@gmail.com telp:085278901457

\section{PENDAHULUAN}

Stroke merupakan penyebab salah satu kematian dan kecacatan di seluruh dunia. Menurut World Health Organitation (WHO) dari 56.400.000 kematian di seluruh dunia pada tahun 2015, lebih dari setengahnya (54\%) adalah karena 10 penyakit salah satunya adalah stroke. Penyakit stroke berada pada tingkat yang paling tinggi menyebabkan kematian sebanyak 15 juta orang pada tahun 2015 dan terbesar secara global dalam 15 tahun terakhir. ${ }^{1}$ Di Indonesia jumlah penderita stroke tahun 2013 diperkirakan 1.236 .825 orang $(7,0 \%) .^{2}$ 
Stroke merupakan gangguan pada otak yang terjadi secara global maupun fokal yang diakibatkan oleh suplai darah ke otak terganggu baik yang disebabkan karena penyumbatan maupun karena pecahnya pembuluh darah. ${ }^{3}$ Kerusakan pada sel otak menyebabkan berbagai macam gangguan fungsi tergantung dimana terjadi penyumbatan seperti gangguan sirkulasi, gangguan fisiologis, gangguan kekuatan otot dan gangguan mobilisasi. ${ }^{4}$ Immobilisasi merupakan gangguan pergerakan secara aktif yang disebabkan oleh berbagai penyakit salah satunya stroke. Immobilisasi jangka panjang akan mengakibatkan gangguan pada pencernaan yaitu kelemahan pada otot abdomen sehingga bisa mengakibatkan konstipasi. ${ }^{5}$

Konstipasi jika tidak diatasi akan mengakibatkan komplikasi pada penyakit lainnya seperti canker kolon, hipertensi arterial, impaksi fekal, hemoroid yang akan berujung kepada kematian. ${ }^{6}$ Salah satu untuk meminimalkan kejadian konstipasi adalah aktifitas fisik yang cukup. Aktivitas fisik yang cukup akan memperkuat otot polos pada usus besar, sehingga akan mempengaruhi peristaltik usus yang akan membantu proses defekasi. ${ }^{7}$ Sebaliknya, jika aktifitas kurang maka otot polos pada pencernaan akan lemah sehingga proses pencernaan akan lambat. ${ }^{8}$ Aktivitas fisik yag cukup akan merangsang terjadinya pergerakan chyme pada kolon sehingga peristaltik usus akan terjadi. ${ }^{9}$

Tujuan dari penelitian ini adalah untuk melihat korelasi aktivitas fisik dengan kejadian konstipasi pada pasien stroke di RS Islam Siti rahmah Padang.

\section{METODE}

Desain penelitian ini adalah cross sectional, populasi penelitian adalah seluruh pasien stroke dengan jumlah sampel sebanyak 54 orang di RS Islam Siti Rahmah Padang, diambil dengan cara simple random sampling. Analisis data menggunakan korelasi Spearman. Aktivitas fsik menggunakan kuosioner International Physical Activity (IPAQ). ${ }^{10}$ Untuk menilai konstipasi menggunakan Constipation Scoring System, yang terdiri dari 7 pertanyaan, dimana skor $\geq$ 15 berarti pasien konstipasi. ${ }^{11}$
HASIL

Tabel 1. Karakteristik responden

\begin{tabular}{llc}
\hline Variabel & \multicolumn{2}{c}{ Frekuensi } \\
\cline { 2 - 3 } & $\mathbf{f}$ & $\%$ \\
\hline Jenis kelamin & 17 & 31,48 \\
Laki-laki & 37 & 68,52 \\
Perempuan & \\
Pendidikan & & 50 \\
SMP & 27 & 9,3 \\
SMA & 5 & 40,7 \\
Perguruan tinggi & 22 & \\
Pekerjaan & & 37,04 \\
IRT & 20 & 27,78 \\
Wiraswasta & 15 & 9,26 \\
BUMN & 5 & 25,92 \\
PNS & 14 & \\
\hline
\end{tabular}

Pada penelitian ini lebih banyak pasien adalah wanita dengan jumlah 37 orang. Pendidikan lebih banyak adalah SMP yaitu berjumlah 27 orang dan status pekerjaan lebih banyak adalah ibu rumah tangga berjumlah 20 orang.

Tabel 2. Distribusi responden berdasarkan konstipasi

\begin{tabular}{lll}
\hline Konstipasi & $\mathbf{n}$ & $\%$ \\
& $\mathbf{( 5 4 )}$ & \\
\hline Ya & 38 & 70,37 \\
Tidak & 16 & 29,62 \\
Total & 54 & 100 \\
\hline
\end{tabular}

Berdasarkan Tabel 2 jumlah pasien stroke yang konstipasi 38 orang $(70,37 \%)$, sedangkan yang tidak konstipasi 16 orang $(29,62 \%)$.

Tabel 3. Distribusi responden berdasarkan aktivitas fisik

\begin{tabular}{|c|c|c|c|c|}
\hline \multirow{3}{*}{$\begin{array}{c}\text { Aktifitas } \\
\text { Fisik }\end{array}$} & \multicolumn{2}{|c|}{ Konstipasi } & \multirow[t]{2}{*}{$\mathbf{p}$} & \multirow[t]{2}{*}{$\mathbf{r}$} \\
\hline & ya & tidak & & \\
\hline & $\mathbf{n}$ & $\mathbf{n}$ & & \\
\hline rendah & 34 & 5 & 0,000 & 0,608 \\
\hline sedang & 4 & 11 & & \\
\hline
\end{tabular}

Tabel 3 memperlihatkan responden dengan aktifitas rendah dan mengalami konstipasi berjumlah 34 orang $(87,18 \%)$. Responden dengan aktifitas 
sedang dan tidak konstipasi berjumlah 11 orang (73,3\%), sedangkan responden yang aktifitas sedang tetapi masih konstipasi berjumlah 4 orang (26,67\%). Analisis data didapatkan ada hubungan antara aktifitas fisik dengan konstipasi dengan $p=0,000$. Tingkat kekuatan korelasi antara aktifitas fisik dan konstipasi adalah sebesar 0,608 , yang berarti adanya hubungan yang kuat antara kedua variabel.

\section{PEMBAHASAN}

\section{Hubungan Aktifitas Fisik Terhadap Konstipasi pada Pasien Stroke}

Hasil penelitian ini didapatkan responden lebih banyak konstipasi dengan aktifitas yang rendah. Hasil uji statistik korelasi Spearman, menunjukan terdapat hubungan yang kuat dan bersifat positif antara aktivitas fisik dan konstipasi pada pasien stroke ( $p=$ $0,000, r=0,608)$. Penelitian ini sejalan dengan yang telah dilakukan oleh García ety al (2013), yaitu terdapat hubungan yang kuat antara aktivitas fisik dan konstipasi. ${ }^{12}$ Penelitian ini didukung oleh penelitian Huang (2014) yang meneliti faktor yang mempengaruhi kejadian konstipasi terhadap 129 orang guru SD. Hasil dari peneltian, diperoleh $p=$ 0,029, yang berarti terdapat perbedaan proporsi antara aktivitas dan kejadian konstipasi, resiko terserang konstipasi fungsional 2 kali lebih besar pada responden dengan aktifitas rendah. ${ }^{13}$

Aktivitas fisik merupakan segala kegiatan fisik yang dilakukan dalam satu hari baik ringan maupun berat. Aktivitas fisik perlu dilakukan untuk kesehatan, melatih melancarkan sirkulasi darah dan meningkatkan kebugaran. ${ }^{12}$ Pada pasien stroke mengalami kesukaran dalam melakukan aktifitas fisik, terlebih pada pasien yang mengalami immobilisasi atau kelumpuhan pada tubuh baik sebagian atau pun keseluruhan. ${ }^{13}$ Keterbatasan aktivitas fisik pada pasien stroke ini bisa menyebabkan konstipasi. ${ }^{14}$

Aktivifitas fisik kurang akan mempengaruhi otot pencernaan salah satunya otot polos usus besar mengalami penurunan fisiologis yang akan berdampak terhadap gangguan defekasi. ${ }^{15}$ Pembentukan feses akan terlambat, ${ }^{16}$ sehingga penyerapan air di dalam usus besar semakin meningkat yang mengakibatkan feses menjadi keras dan sulit untuk dikeluarkan. ${ }^{18}$
Aktivitas fisik yang cukup akan memperkuat otot polos pada usus besar, sehingga akan mempengaruhi peristaltik usus yang akan membantu proses defekasi. ${ }^{17}$ Sebaliknya, jika aktifitas kurang maka otot polos pada pencernaan akan lemah sehingga proses pencernaan akan lambat.$^{18}$ Pada pasien stroke perlu diberikan aktifitas yang cukup untuk meminimalkan konstipasi sehingga tidak terjadi komplikasi penyakit lain. ${ }^{19}$ Penelitian lain menunjukkan ada banyak faktor yang mempengaruhi konstipasi, seperti aktifitas fisik dan makanan. ${ }^{20}$ Aktivitas fisik yag cukup akan merangsang terjadinya pergerakan chyme pada kolon sehingga peristaltik usus akan terjadi. ${ }^{21}$ Kejadian penurunan fungsi pada otot maka akan sulit untuk mengembalikan fungsi tersebut. ${ }^{22}$

Penelitian ini juga didukung oleh Sari (2016), yaitu konstipasi pada lansia bisa diminimalkan dengan meningkatkan aktifitas fisik. ${ }^{23}$

\section{SIMPULAN}

Konstipasi pada pasien stroke bisa diminimalkan dengan aktifitas yang cukup.

\section{UCAPAN TERIMAKASIH}

Terimakasih kepada Rektor Universitas Andalas, Dekan Fakultas keperawatan, Ketua prodi Magister Keperawatan dan seluruh dosen di Fakultas Keperawatan Universitas Andalas yang telah mendukung penelitian ini.

\section{DAFTAR PUSTAKA}

1. World Health Organizatioan (WHO). Global status report on non communicable diseases 2014. London: Chatham House. 2014.hlm.176.

2. Dinas Kesehatan Sumatera Barat (Dinkes Sumbar). Profil kesehatan tahun 2013. Dinkes Sumbar; 2013.

3. Li J, Yuan M, Liu Y, Zhao Y, Wang J, Guo W. Incidence of constipation in stroke patients: a systematic review and meta-analysis. Medicine (Baltimore). 2017;96(25):e7225.

4. Mazzoleni S, Tran V, Dario P, Posteraro F. Wrist robot-assisted rehabilitation treatment in subacute and chronic stroke patients: from distal to proximal motor recovery. IEEE Trans Neural Syst Rehabil Eng. 2018;PP(i):1-1. 
5. Emly, M, Marriott A. Revisiting constipation management in the community. $\mathrm{Br} \mathrm{J}$ Community Nurs. 2017;22(4):168-72.

6. El-saman SEA, Ahmed HHE. Constipation occurrence among critically III patients. IOSR J Nurs Heal Sci. 2017;6(2):70-9.

7. Wardhani RZ, Martini S. Faktor yang berhubungan dengan pengetahuan tentang stroke pada pekerja institusi pendidikan tinggi. Jurnal Berkala Epidimilogy. 2014;2(1):13-23.

8. Gacouin A, Camus C, Gros A, Isslame S, Marque $S$, Lavoué $S$, et al. Constipation in long-term ventilated patients: associated factors and impact on intensive care unit outcomes. Crit Care Med. 2010;38(10):1933-8.

9. Lamas K. Using massage to ease contipation. Nursing Times. 2011;107(4):27.

10. Noor $A$, Ismail $R$, Ismail $\mathrm{NH}$, Health $\mathrm{O}$. Psychometric properties of the Malay-translated general practice physical activity questionnaire among shipyard workers. Biomed Mater. 2017;72(6):350-5.

11. Agachan $F$, Chen $T$, Pfeifer J, Reissman $P$, Wexner SD. A Constipation scoring system to simplify evaluation and management of constipated patients. Pubmed. 2017(3):681-5.

12. García VEJ, Salado VE. Food intake, nutritional status and physical activity between elderly subjects with and without chronic vonstipation. a comparative study. Biomater Apply. 2013;81(3):199-204.

13. Huang R, Ho S, Lo W, Lam T. Physical activity and constipation hongkong adolescent. Arthoplasty. 2014;9(2):1-5

14. Suddart B. Medical-surgical nursing (terjemahan). Jakarta: EGC; 2012.
15. Hospital, S. Managing constipation in older people in hospital. American Society of Colon. 2015;111(22):19-21.

16. Yan K, Wong A. The effects of abdominal massage and bowel recipe for the relief of constipation among residents in a care and attention home for persons with physical disability in Hong Kong: How did this study begin wheel chair bound institutionalized. J Nurse. 2013; 59 (2):63.

17. Price SW. Patofisiologis. konsep klinis proses penyakit. Pendit Bu, perterjemah. Jakarta: EGC; 2010.

18. Peate I, Nair M. Fundamental of anatomy and physiology workbook: a study guide for nurses and healthcare student. USA: Willey Blackwell; 2016;(3);113-24

19. Marieb E, Keller S. Human anatomy. New York: Delmar; 2015.hlm.657.

20. Keiko A, Massayasu S, Sasaki S. Dietary intake, physical activity, and time management are associated with constipation in preschool children in Japan. Behavioral Sciences. 2017; 26 (September 2015):118-29.

21. Dukas L, Willett WC, Giovannucci EL. Association between physical activity, fiber intake, and other lifestyle variables and constipation in a study of women. Elsevier. 2013;98(8):88-9

22. Ardi M. Analisis hubungan ketidak mampuan fisik dan kognitif dengan keputus asaan pada pasien stroke di Makassar [tesis]. Depok: Fakultas IImu Keperawatan Universitas Indonesia; 2011.hlm.14

23. Sari AD, Wirajtmadi B. Hubungan aktivitas fisik dengan kejadian konstipasi pada lansia di kota Madiun. Media Gizi Indonesia. 2016;11(1): 40-7. 